\title{
Unusual Feeding in Adult Gelechiidae Moth Tuta Absoluta (Meyrick, 1917)
}

\author{
Raul BAETAN ${ }^{1}$, Ion OLTEAN ${ }^{1}$, Rocco ADDANTE ${ }^{2}$, Francesco PORCELLI ${ }^{2 *}$ \\ ${ }^{1}$ Departamentul de Protecția Plantelor, Facultatea de Agricultură, Universitatea de Științe Agricole și \\ Medicină Veterinară Cluj - Napoca, Romania \\ ${ }^{2}$ Dipartimento di Scienze del Suolo, della Pianta e degli Alimenti (DiSSPA - UNIBA Aldo Moro Sez. \\ Entomologia e Zoologia, Bari, Italy \\ * corresponding author: francesco.porcelli@uniba.it
}

Bulletin USAMV series Agriculture 72(1)/2015

Print ISSN 1843-5246; Electronic ISSN 1843-5386

DOI 10.15835/buasvmcn-agr: 11144

\begin{abstract}
Introduction: The tomato leaf miner Tuta absoluta (Meyrick, 1917) is a key pest for solanaceous crops, mostly tomato and potato, in many areas of the World. Aims: In this study we present evidences that T. absoluta adults, both males and females, feed on tomato leaves by proboscis. Materials and Methods: Observation were given by a digital camera-equipped stereoscope and confirmed by a Cryo-SEM. Results: We describe and illustrate the adult feeding behaviour and the consequent wounds and scars on the leaves. Discussion and conclusions: A discussion about the role of this unusual behaviour in tomato leafminer biology is given.
\end{abstract}

Keywords: adult feeding, solanaceous crops, Tuta absoluta.

\section{INTRODUCTION}

Tuta absoluta, an invasive pest originated from South America is able to destroy tomato crops in open field and greenhouses in several days (Filho et al., 2000; Gomide et al., 200l). Until now it was considered that only tomato leafminer larvae could feed on plant tissues but this study proves that also adults are able to feed on leaves.

\section{MATERIANLS AND METHODS}

T. absoluta adults necessary for the present study were reared in the laboratory at $23^{\circ} \mathrm{C}$ and $70 \%$ RH. The tomato host plants were grown in pots of $10 \mathrm{~cm}$ diameter, each plant had 6-8 completely healthy true leaves to obtain an evidence of adult feeding.

The behaviour of T. absoluta was studied with a Motic and Leitz stereomicroscope. The leaves damaged by leafminer were examined and imaged by a Zeiss Universal compound microscope, a Zeiss Tessovar macro system and a Hitachi TM3000 Cryo-SEM.

\section{RESULTS AND DISCUSSION}

The proboscis of T. absoluta is about $1.4 \mathrm{~mm}$ long, 2.5 times coiled and divided in three parts: proximal, middle and distal. When adults settled on the leaves they uncoiled the proboscis starting to sting the tissues for feeding. The action of the proboscis on the leaves lasts less than one second and can be single or repeated. The strips revealing the wounds left on the superior surface of the leaves correspond to the proboscis action. These wounds are bordered by a yellow-green edge, their shape is slightly concave and their floor is marbled by a specific pattern. The wounds can be found in a line or in group of 3-4 elements. 


\section{CONCLUSIONS}

This is the first report of the feeding behaviour of $T$. absoluta adults on tomato leaves. This behaviour can lead to changes in the trophic and non-trophic interactions between this pest and the host plant.

Discovering that T. absoluta adults are able to feed on the leaves can lead to new and more effective control methods of this pest.

Acknowlwdgements. This paper was published under the frame of European Social Fund, Human
Resources Development Operational Programme 2007-2013, project no. POSDRU/159/1.5/ S/132765.

\section{REFERENCES}

1. Filho MM, Vilela EF, Jham GN, Attygalle A, Svatos A, Meinwald J (2000). Initial Studies of Mating Disruption of the Tomato Moth, Tuta absoluta (Lepidoptera: Gelechiidae) Using Synthetic Sex Pheromone. Journal of the Brazilian Chemical Society 11(6):621-628.

2. Gomide EVA, Vilela EF, Picanço M (2001). Comparação de procedimentos de amostragem de Tuta absoluta (Meyrick) (Lepidoptera: Gelechiidae) em Tomateiro Estaqueado. Neotropical Entomology Vacaria 30(4):697-705. 